\title{
Ants as vectors of pathogenic microorganisms in a hospital in São Paulo county, Brazil
}

\author{
Heros J Máximo ${ }^{1,2^{*}}$, Henrique L Felizatti ${ }^{3}$, Marcela Ceccato ${ }^{4}$, Priscila Cintra-Socolowski ${ }^{4}$ \\ and Ana Laura R Zeni Beretta ${ }^{5^{*}+}$
}

\begin{abstract}
Background: The present study aimed to identify and characterize the presence of bacteria carried by ants, and check the distribution of these ants in the physical confines of a medium-sized hospital in São Paulo county, Brazil.

Methods: The ants were collected from March 2012 to February 2013. Attractive non-toxic baits were used to catch the ants, and the sectors considered for the study were medical wards, outdoor areas, obstetric unit, reception area, kitchen, surgical centres, paediatric clinic and intensive care unit. Captured ants were classified using taxonomic keys and subsequently immersed in Brain Heart Infusion broth.

Results: Paratrechina spp. and Monomorium floricola ants were found most frequently in the hospital. Ants had a high capacity for carrying bacteria, and the isolates comprised 68.8\% Gram-positive, spore-producing bacilli (Bacillus spp. and Listeria spp.); 14.7\% Gram-negative bacilli (Pseudomonas aeruginosa and Klebsiella spp.); and 16.4\% Gram-positive cocci (Streptococcus spp. and Staphylococcus aureus). Among the areas being evaluated, the medical wards had the largest number of ants captured, and therefore the most bacteria.

Conclusions: Ants in hospitals may carry both Gram-positive and Gram-negative bacteria, and methods of controlling urban ants should be adopted and strictly adhered to, to minimize the risk of infection in hospital patients.
\end{abstract}

Keywords: Nosocomial infection, Bacteria, Ants, Pathogenic microorganisms, Nosocomial environment

\section{Background}

Ants are social insects that live in symbiosis with humans and readily adapt to urban environments. They can affect the quality of human life, because of the possibility of causing damage and threats to health. The hospital environment is one of the main areas for ants and their presence can facilitate the propagation and spread of pathogenic microorganisms [1,2].

In Brazil, there are approximately 2,000 known species of ants, and 20-30 are considered to be an urban plague [3]. The dispersion and increasing populations of urban ants are facilitated by several factors, the most important of which are: polygyny, unicolonial populations, migration of colonies, polidomic colonies, reproduction by

\footnotetext{
* Correspondence: heros.maximo@icloud.com; analaura@uniararas.br ${ }^{\dagger}$ Equal contributors

${ }^{1}$ Postgraduate Program - Master's Degree in Biomedical Science/Uniararas, Araras, São Paulo, Brasil

${ }^{5}$ Postgraduate Program in Biomedical Science/Health Science Nucleus, Hermínio Ometto University Centre (UNIARARAS), Araras, São Paulo, Brazil Full list of author information is available at the end of the article
}

fragmentation, small nest structure and workers with reduced size and without nuptial flight [3].

The occurrence of ants in hospitals has become a research focus owing to the exposure of patients and health professionals to the risks associated with these insects. The quality of healthcare assistance in urban hospitals also suffers from the problem of an increase in microbial vectors. Studies in two hospitals in Northeast Brazil have warned about the specific role of ants (Hymenoptera: Formicidae) in the transport of pathogenic bacteria associated with hospital environments [4]. Among the factors that favour the presence of ants in urban hospitals are: the arrangement of architectural structures; nearby homes where ants are present, which favours migration of ants; the packaging of some medications may harbour nests of ants, bringing them into the internal environment; the provision and maintenance of air conditioning; the large number of people 
with clothes and objects that may contain ant nests, and attractions such as food scraps and organic material $[5,6]$.

Nosocomial infection has attracted much interest in the scientific community because of the high rates of morbidity and mortality in hospitalized patients $[7,8]$. Its occurrence depends on the sanitary conditions and the presence of vectors of pathogenic microorganisms. Among social insects, ants make numerous parasitic and mutualistic relationships and develop multiple interactions with animals, plants, fungi and bacteria [2]. This carries a great risk of infection in hospitals on account of the mobility of ants within the hospital environment $[7,9,10]$.

Considering the ability of ants to carry and disseminate pathogens in the hospital environment, we aimed to identify and characterize the presence of bacteria associated with ants, and the distribution of these ants within the physical confines of a medium-sized hospital in São Paulo county, Brazil.

\section{Methods}

\section{Bioethics committee permission}

This study was approved under the legal agreement 013/ 2012 by the Ethics Committee for Animal Use - CEUA of Hermínio Ometto Foundation - UNIARARAS, Araras, São Paulo, Brazil.

\section{Capture and identification of ants}

To catch the ants, we used 15-mL Falcon-type tubes, containing $5 \mathrm{~mL}$ sterile non-toxic attractive bait [11], packed in a plastic box $(28 \times 15 \times 13 \mathrm{~cm})$, previously sterilized by non-ionizing radiation. These tubes allowed entry of the ants, and were divided into sampling points in the morning for a period of $2 \mathrm{~h}$ (between 10:00 and 12:00 h). The samples were collected monthly during March 2012 to February 2013 in a hospital in São Paulo county, Brazil. The collection points were medical wards, outdoor areas, obstetric unit, reception area, kitchen, surgical centres, paediatric clinic and intensive care unit (ICU). These areas were selected because of the higher incidence of ants and criteria for risk of infection of patients $[9,12]$. Captured ants were subjected to morpho-dyeing; cultural, biochemical and microbiological analysis; and subsequently fixed in $80 \%$ alcohol. The ants were mounted on entomological pins and identified using pictorial keys [4] keys and complete keys [13]. The classification of ants was performed in collaboration with the Centre for the Study of Social Insects (CEIS) of the Institute of Biosciences of Rio Claro - UNESP, São Paulo, Brazil.

\section{Microbiological analysis}

Captured ants were immersed in Brain Heart Infusion (BHI) broth, incubated in a microbiological growth medium for $24 \mathrm{~h}$ at $36 \pm 1^{\circ} \mathrm{C}$, and samples that showed growth were plated on BHI agar by the method of exhaustion. The isolated pure colonies were seeded in specific environments for isolating particular microorganisms and subjected to morphological, cultural and biochemical analyses [14]. Chromogenic culture media for isolation and identification of Gram-positive cocci, and identification panels for glucose-fermenting and glucose-non-fermenting Gram-negative bacilli (Probac Brasil, São Paulo, Brazil). Microbiological analysis was performed at the Microbiology Laboratory, Anhanguera University Centre, Leme, São Paulo, Brazil and the Centre for Health Sciences, Hermínio Ometto University Centre (UNIARARAS), Araras, São Paulo, Brazil.

\section{Statistical analysis}

In the captured ants, we calculated the absolute frequency, accumulated absolute frequency, relative frequency, and cumulative relative frequency of the isolated microorganisms. Fisher's exact test was used to evaluate the hypothesis that the proportions of microorganisms were related to the type of ant. The confidence interval for differences in the evaluated proportions was used [15-17]. Statistical analyses were performed in the Department of Statistics, Federal University of Goiás, Goiás, Brazil.

\section{Results}

Seventy ants were captured from the evaluated sites; of which, $62.8 \%$ were of the genus Paratrechina and 25.7\% were Monomorium floricola. Among the other ants found $7.1 \%$ were from the genus Dorymyrmex, $2.8 \%$ from Pheidole and 1.4\% from Brachymyrmex (Table 1).

Among the bacteria isolated from the integument of captured ants, $45.7 \%$ were Bacillus spp., and other bacteria were Listeria spp. (10\%), Streptococcus spp. (7.1\%), Pseudomonas aeruginosa (7.1\%), Klebsiella spp. (4.2\%), Staphylococcus aureus (4.2\%), Arcanobacterium spp. (2.8\%), Proteus spp. (2.8\%), Micrococcus luteus (1.4\%) and Staphylococcus epidermidis (1.4\%). In addition, $12.8 \%$ of the ants showed no microbial growth. Among the isolated bacteria, $\sim 68.8 \%$ were Gram-positive bacilli, 16.4\% were Gram-positive cocci and about 14.7\% were Gram-negative bacilli. Regarding Gram-negative bacilli, 55.5\% were isolated from $M$. floricola ants, $22.2 \%$ from Dorymyrmex spp., 11.1\% from Brachymyrmex spp. and $11.1 \%$ from Pheidole spp. For the Gram-positive bacilli, 78.5\% were isolated from Paratrechina spp., 9.5\% from $M$. floricola, $7.15 \%$ from Dorymyrmex spp. and $4.7 \%$ from Pheidole spp. Gram-positive cocci were isolated from two different types of ants, 70\% from the integument of M. floricola and 30\% from Paratrechina spp. (Table 2).

Considering only $M$. floricola and Paratrechina spp., the Fisher's exact test was used to evaluate the hypothesis that the proportions of organisms were related to the type of ants (Table 3). Because there was a relationship 
Table 1 Frequencies of ants and microorganisms in a hospital in São Paulo county, March 2012 to February 2013

\begin{tabular}{|c|c|c|}
\hline Ant species & Absolute frequency of ants & Absolute frequency of microorganisms \\
\hline Paratrechina spp. & 44 & $\begin{array}{l}24 \text { Bacillus spp.; } 7 \text { Listeria spp.; } 2 \text { Arcanobacterium spp.; } 1 \\
\text { Streptococcus spp.; } 1 \text { Pseudomonas aeruginosa; } 1 \\
\text { Micrococcus luteus; } 1 \text { Sthaphylococcus epidermidis }\end{array}$ \\
\hline M. floricola & 18 & $\begin{array}{c}4 \text { Bacillus spp.; } 4 \text { Streptococcus spp.; } 3 \text { Pseudomonas } \\
\text { aeruginosa; } 3 \text { Staphylococcus aureus; } 2 \text { Proteus spp.; } 2 \\
\text { no microbial growth }\end{array}$ \\
\hline Dorymyrmex spp. & 5 & 3 Klebsiella spp.; 2 Bacillus spp. \\
\hline Pheidole spp. & 2 & 2 Bacillus spp. \\
\hline Brachymyrmex spp. & 1 & 1 Pseudomonas aeruginosa \\
\hline
\end{tabular}

between the variables, we tried to measure individual differences in the proportions of bacteria isolated from $M$. floricola and Paratrechina spp. These individual differences were evaluated using confidence intervals for differences in proportions. Table 4 shows a summary of the proportions, confidence intervals and the conclusions of these intervals.

We observed that the presence of Streptococcus spp, Proteus spp, $P$. aeruginosa and $S$. aureus was greater in M. floricola than Paratrechina spp. In contrast, Bacillus spp. were more prevalent in Paratrechina spp. compared with $M$. floricola. These differences were significant, with 95\% confidence.

The environment with the highest percentage of ants captured was the medical clinic, with $80 \%$ of the total, followed by outdoor areas (8.5\%), obstetric unit (8.5\%) and reception room $(2.8 \%)$. No ants were found in the kitchen, surgical centres, paediatric clinic and ICU. These data are listed in Table 5. Considering only the environments where ants were captured, in the medical clinic, $64.3 \%$ of the ants were from the genus Paratrechina, followed by M. floricola (26.8\%), Pheidole (3.6\%), Dorymyrmex spp. (3.6\%) and Brachymyrmex spp. (1.8\%). Outside the hospital, $50 \%$ of the ants are were Dorymyrmex spp., while the other 50\% were Paratrechina spp. In the obstetrics unit, $83.3 \%$ of the ants were Pratrechina spp., followed by $16.7 \% \mathrm{M}$. floricola. In the reception area, all the ants were $M$. floricola.

Table 2 Bacteria isolated from ants captured in a hospital in São Paulo county, March 2012 to February 2013

\begin{tabular}{cccc}
\hline \multicolumn{4}{c}{ Microorganisms } \\
\hline Ants & $\begin{array}{c}\text { Gram-negative } \\
\text { bacilli }\end{array}$ & $\begin{array}{c}\text { Gram-positive } \\
\text { bacilli }\end{array}$ & $\begin{array}{c}\text { Gram-positive } \\
\text { cocci }\end{array}$ \\
\hline Brachymyrmex spp. & 1 & 0 & 0 \\
Dorymyrmex spp. & 2 & 3 & 0 \\
M. floricola & 5 & 4 & 7 \\
Paratrechina spp. & 1 & 33 & 3 \\
Pheidole spp. & 0 & 2 & 0 \\
\hline
\end{tabular}

\section{Discussion}

Considering only the places where ants were captured, in the medical clinic, $64.3 \%$ of the ants found were from the genus Paratrechina. Fowler et al. [9], Bueno et al. [10] and Zarzuela et al. [11] also recorded this genus in Brazilian hospitals. Monomorium floricola species represented $26.8 \%$ of the ants found in the same environment. This species is considered to be one of the major existing exotic species of ant in Bueno and Campos-Farinha, Brazil [4]. The genus Pheidole represented 3.6\% of ants captured in the same environment, and this is a native species in Brazil and considered by Campos-Farinha et al. [18] to be a major urban plague. The genus Dorymyrmex accounted for $3.6 \%$ of ants captured in the clinic, while Brachymyrmex spp. represented $1.8 \%$. In households, ants use cracks in tiles, windows and doorframes to form nests, and the construction of nests is not prevented by well-maintained physical structures [19].

From the 70 samples of aseptically collected ants, 61 (87.1\%) had pathogenic bacteria in their integuments, which agrees with previous studies [1-3,5,7-9,12,20-23]. Regarding Gram-positive bacilli, it is noteworthy that their ability to form endospores allows them to become established in places of great environmental instability. Streptococcus spp. and Klebsiella spp. have been isolated from ants in hospital environments and identified as multiresistant to antibiotics [20]. Pseudomonas aeruginosa represented $7.1 \%$ of bacteria found. It is frequently isolated from clinical samples, causing infections that are usually associated with sites that have a tendency towards

Table 3 Relationship between ants and bacteria from a hospital in São Paulo county, March 2012 to February 2013

\begin{tabular}{|c|c|c|c|c|c|c|c|c|c|c|}
\hline Ants & Arc & Bac & Str & Lis & Mic & Pro & Pse & NMG & Sta & Ste \\
\hline M. floricola & 0 & 4 & 4 & 0 & 0 & 2 & 3 & 2 & 3 & 0 \\
\hline Paratrechina spp. & 2 & 24 & 1 & 7 & 1 & 0 & 1 & 7 & 0 & 1 \\
\hline
\end{tabular}


Table 4 Proportions of bacteria in ants in a hospital in São Paulo county, March 2012 to February 2013

\begin{tabular}{|c|c|c|c|c|c|}
\hline & Arcanobacterium spp. & Bacillus spp. & Streptococcus spp. & Listeria spp. & M. luteus \\
\hline M. floricola & $0.00 \%$ & $22.22 \%$ & $22.22 \%$ & $0.00 \%$ & $0.00 \%$ \\
\hline Paratrechina spp. & $4.55 \%$ & $54.55 \%$ & $2.27 \%$ & $15.91 \%$ & $2.27 \%$ \\
\hline $95 \% \mathrm{Cl}$ & $(-15.26 \% ; 13.54 \%)$ & $(-52.92 \% ;-4.99 \%)$ & $(-15.26 \% ; 13.54 \%)$ & $(-29.49 \% ; 2.76 \%)$ & $(-11.93 \% ; 15.68 \%)$ \\
\hline \multirow[t]{2}{*}{ Result } & $N S^{*}$ & $\begin{array}{c}\text { Paratrechina spp. } \\
<\text { M. floricola }\end{array}$ & $\begin{array}{c}\text { Paratrechina spp. } \\
<\text { M. floricola }\end{array}$ & $N S^{*}$ & $N S^{*}$ \\
\hline & Proteus spp. & P. aeruginosa & Without growth & S. aureus & S. epidermidis \\
\hline M. floricola & $11.11 \%$ & $16.67 \%$ & $11.11 \%$ & $16.67 \%$ & $0.00 \%$ \\
\hline Paratrechina spp. & $0.00 \%$ & $2.27 \%$ & $15.91 \%$ & $0.00 \%$ & $2.27 \%$ \\
\hline $95 \% \mathrm{Cl}$ & $(2.32 \% ; 33.01 \%)$ & $(0.80 \% ; 37.43 \%)$ & $(-21.35 \% ; 18.76 \%)$ & (5.79\%; 39.43\%) & $(-11.93 \% ; 15.68 \%)$ \\
\hline Result & $\begin{array}{c}\text { Paratrechina spp. } \\
<\text { M. floricola }\end{array}$ & $\begin{array}{c}\text { Paratrechina spp. } \\
<\text { M. floricola }\end{array}$ & $N S^{*}$ & $\begin{array}{c}\text { Paratrechina spp. } \\
<\text { M. floricola }\end{array}$ & $N S^{*}$ \\
\hline
\end{tabular}

*NS means: not statistically significant.

humidity, such as tracheostomy, indwelling catheters, burns and exudative wounds.

According to Tresoldi et al. [24], the frequency of microorganisms isolated from nosocomial infection was 56.5\% Gram-negative bacilli, 20.9\% Gram-positive cocci and $9 \%$ yeast. The possibility of transmission of microorganisms and their presence in the hospital environment may act to maintain or increase such findings.

In our study, among the bacteria isolated from the integument of captured ants, 4.2\% were Klebsiella spp. Cassettari et al. [25] reported that this bacterium was responsible for a $5.6 \%$ rate of urinary tract infections, conjunctivitis and bacteraemia in a public hospital in São Paulo, Brazil. They also showed that S. aureus accounted for $4.2 \%$ of the bacteria found, and according to Nagao et al. [26], it is an important causative agent of nosocomial infection, mainly primary bloodstream infections. Infections caused by $S$. epidermidis include endocarditis, intravenous catheter infection, peritonitis associated with peritoneal dialysis catheter, bacteraemia, wound infections, prosthesis infections and infections of the upper airways $[7,14]$.

Table 5 Number of ants captured according to hospital environment, March 2012 to February 2013

\begin{tabular}{lcc}
\hline Environment & Total ants & *Days with observation \\
\hline Medical clinic & 56 & 6 \\
External area & 6 & 3 \\
Obstetric clinic & 6 & 2 \\
Reception room & 2 & 1 \\
Kitchen & 0 & 0 \\
Surgical centre & 0 & 0 \\
Paediatric clinic & 0 & 0 \\
Intensive care unit & 0 & 0 \\
\hline
\end{tabular}

*Days with observation of ants within the specified environment.
In studies by Costa et al. [7], bacteria were isolated from ants in hospitals; particularly Pseudomonas spp., Staphylococcus spp. and Micrococcus spp. Carneiro et al. [27] have also observed Staphylococcus spp. and Klebsiella spp. as pathogenic bacteria carried by ants.

Some of the bacteria isolated in the present study may present a risk to health, so it is necessary to consider several factors that may cause infection. Considering that ants can be one of the factors responsible for nosocomial infection, preventive measures and control of urban ants should be implemented to reduce the risks that these vectors present.

\section{Conclusions}

Our results are clearly of relevance to public health, particularly hospital infection control. We believe that knowledge about the biology, ecology and habits of ants may help to reduce the problems caused by ants in hospitals. The presence of ants in this environment must be seen as a warning to the Commission of Hospital Infection Control and all multidisciplinary hospital staff. Therefore, the development of basic preventive measures and the control of ants must be undertaken.

\section{Competing interests}

All the authors declare that they have no competing interest that could have interfered with the analysis and interpretation of the results of the present study.

\section{Authors' contributions}

HJM contributed to the capture of ants, classification of ants, microbiological analysis, statistical analysis, design of the study and preparation of the article. HLF contributed to design of the study and statistical analysis, statistical modelling and data compilation. MC directly contributed to the classification of ants. PC-S contributed to the supervision and design of the research, capture and classification of ants, and writing the article. ALRZB contributed to the design of the research, microbiological analysis, classification of microorganisms and writing the article. All authors read and approved the final manuscript. 


\section{Acknowledgements}

We thank the Institute for Applied Research and Educational Development IPADE of Anhanguera Educacional, Valinhos, São Paulo, Brazil and Study Centre Social Insects (CEIS) of Bioscience Institute of UNESP, Rio Claro, São Paulo, Brazil.

\section{Funding}

This work was supported by the National Foundation for Development of Private Higher Education - FUNADESP, Brazil.

\section{Author details}

${ }^{1}$ Postgraduate Program - Master's Degree in Biomedical Science/Uniararas, Araras, São Paulo, Brasil. ${ }^{2}$ Health and Agrarian Science Department of Anhanguera University Centre, Leme, São Paulo, Brazil. ${ }^{3}$ Statistics Department of Federal University of Goiás, Goiás, Brazil. ${ }^{4}$ Social Insects Study Centre (CEIS) of Bioscience Institute of Rio Claro, UNESP, Rio Claro, São Paulo, Brazil. ${ }^{5}$ Postgraduate Program in Biomedical Science/Health Science Nucleus, Hermínio Ometto University Centre (UNIARARAS), Araras, São Paulo, Brazil.

\section{Received: 29 October 2013 Accepted: 5 August 2014}

Published: 20 August 2014

\section{References}

1. Boursaux-Eude C, Gross R: New insights symbiotic associations between ants and bacteria. Res Microbiol 2000, 519:513-519.

2. Campos RBF, Silva CG: Formigas (Hymenoptera: Formicidae) urbanas em um hospital no município de Luz, Estado de Minas Gerais. Acta Sci Health Sci 2010, 32:29-34.

3. Bueno OC, Campos-Farinha AEC: As Formigas Domésticas. In Insetos e Outros Invasores de Residências. Edited by Mariconi FAM. Piracicaba: FEALQ; 1999:135-180.

4. Fontana R, Wetler RMDC, Aquino RSS, Andrioli JL, Queiroz GRG, Ferreira SL, Nascimento ICD, Delabie JHC: Pathogenic bacteria dissemination by ants (Hymenoptera: Formicidae) in two hospitals in northeast Brazil. Neotrop Entomol 2010, 39:655-663.

5. Zarzuela MFM, Pacheco LB, Campos-Farinha AEC, Peçanha MP: Avaliação do potencial das formigas como vetores de bactérias em ambientes residenciais e cozinhas semi-industriais. Arq Inst Biol 2002, 69(Suppl):1-306.

6. Bragança MAL, Lima JD: Composição, abundância e índice de infestação de espécies de formigas em um hospital materno-infantil de Palmas, TO. Neotrop Entomol 2010, 39:124-130.

7. Costa SB, Pelli A, Carvalho GP, Oliveira AG, Silva PR, Teixeira MM, Martins E, Terra APS, Resende EM, Oliveira CCHB, Morais CA: Formigas como vetores mecânicos de microrganismos no Hospital Escola da Universidade Federal do Triângulo Mineiro. Rev Soc Bras Med Trop 2006, 39:527-529.

8. Maia ZPG, Gusmão AB, Barros TF: Formiga como fator de risco de infecções nosocomiais. Sabios 2009, 4:47-51.

9. Fowler $\mathrm{HG}$, Bueno OC, Sadatsune T, Montelli A: Ants as potential vectors of pathogens in hospitals in the state of São Paulo. Insect Sci Applic 1993, 14:367-370.

10. Bueno OC, Fowler HG: Exotic Ants and Native Ant Fauna of Brazilian Hospitals. In Exotic Ants: Biology, Impact and Control of Introduced Species. Edited by Williams DF. Boulder, CO: Westview Press; 1994:191-198.

11. Zarzuela MFM, Ribeiro MCC, Campos-Farinha AEC: Distribuição de formigas urbanas em um hospital da Região Sudeste do Brasil. Arq Inst Biol 2002, 69:85-87.

12. Beatson SH: Pharaoh's as pathogen vectors in hospitals. Lancet 1972, $1: 425-427$.

13. Bolton B: Identification Guide to the Ant Genera of the World. Boston: Harvard University Press; 1994.

14. Konemam EW, Allen SD, Janda WM, Procop GW, Schreckenberger PC, Woods GL: Diagnóstico Microbiológico - Texto e Atlas Colorido. 6th edition. Rio de Janeiro: Guanabara Koogan; 2008.

15. Agresti A: Categorical Data Analysis. 2nd edition. New York: Wiley; 2002.

16. Mee RW: Confidence bounds for the difference between two probabilities. Biometrics 1984, 40:1175-1176.

17. Miettinen OS, Nurminen M: Comparative analysis of two rates. Stats Med 1985, 4:213-226

18. Campos-Farinha AEC, Bueno OC, Campos MCG, Kato LM: As formigas urbanas no Brasil: retrospecto. Arq Inst Biol 2002, 64:129-133.
19. Bueno OC, Campos-Farinha AEC: Formigas urbanas: comportamento das espécies que invadem as cidades brasileiras. Vetores Pragas 1998, 1:13-16.

20. Moreira DDO, Morais V, Motta OV, Campos-Farinha AEC, Tonhasca JA: Ants as carriers of antibiotic-resistant bacteria in hospitals. Neotrop Entomol 2005, 34:34-39.

21. Cintra-Socolowski P: Histórico sobre as pesquisas com formigas em ambientes hospitalares no Brasil. Biológico 2007, 69(Suppl. 2):35-38.

22. Tanaka II, Viggiani AMFS, Person OC: Bacteria carried by ants in a hospital environment. Arq Med ABC 2007, 32:60-63.

23. Pesquero MA, Filho JE, Carneiro LC, Feitosa SB, Oliveira MAC, Quintana RC: Formigas em ambiente hospitalar e seu potencial como transmissoras de bactérias. Neotrop Entomol 2008, 37:472-477.

24. Tresoldi AT, Branchini MLM, Filho DCM, Padoveze MC, Dantas SPE, Reginato L, Nowakonski AV, Oliveira UM, Trabasso P: Relative frequency of nosocomial microorganisms at UNICAMP University Hospital from 1987 to 1994. Rev Inst Med Trop de São Paulo 1997, 39:6-13.

25. Cassettari VC, Silveira IR, Balsamo AC, Franco F: Surto em berçário por Klebsiella pneumoniae produtora de beta-lactamase de espectro estendido atribuído à colonização de profissional de saúde portador de onicomicose. J Pediatr 2006, 82:313-316.

26. Nagao M, Okamoto A, Yamada K, Hasegawa T, Hasegawa Y, Ohta M: Variations in amount of TSST-1 produced by clinical methicillin resistant Staphylococcus aureus (MRSA) isolates and allelic variation in accessory gene regulator (agr) locus. BMC Microbiol 2009, 9:1-5.

27. Carneiro LC, Carvalhares TT, Pesquero MA, Quintana RC, Feitosa SB, Elias FJ, Oliveira MAC: Identificação de bactérias causadoras de infecção hospitalar e avaliação da tolerância a antibióticos. NewsLab 2008, 86:106-114.

\section{doi:10.1186/1756-0500-7-554}

Cite this article as: Máximo et al: Ants as vectors of pathogenic microorganisms in a hospital in São Paulo county, Brazil. BMC Research Notes 2014 7:554

\section{Submit your next manuscript to BioMed Central and take full advantage of:}

- Convenient online submission

- Thorough peer review

- No space constraints or color figure charges

- Immediate publication on acceptance

- Inclusion in PubMed, CAS, Scopus and Google Scholar

- Research which is freely available for redistribution

Submit your manuscript at www.biomedcentral.com/submit
C Biomed Central 